University of Nebraska - Lincoln

DigitalCommons@University of Nebraska - Lincoln

2012

\title{
Ducks and Passerines Nesting in Northern Mixed-Grass Prairie Treated With Fire
}

Todd A. Grant

United States Fish and Wildlife Service, todd_grant@fws.gov

Terry L. Shaffer

United States Geological Survey, tshaffer@usgs.gov

Elizabeth M. Madden

United States Fish and Wildlife Service

Gordon B. Berkey

United States Fish and Wildlife Service

Follow this and additional works at: https://digitalcommons.unl.edu/usgsnpwrc

Grant, Todd A.; Shaffer, Terry L.; Madden, Elizabeth M.; and Berkey, Gordon B., "Ducks and Passerines Nesting in Northern Mixed-Grass Prairie Treated With Fire" (2012). USGS Northern Prairie Wildlife Research Center. 276.

https://digitalcommons.unl.edu/usgsnpwrc/276

This Article is brought to you for free and open access by the US Geological Survey at DigitalCommons@University of Nebraska - Lincoln. It has been accepted for inclusion in USGS Northern Prairie Wildlife Research Center by an authorized administrator of DigitalCommons@University of Nebraska - Lincoln. 


\title{
Ducks and Passerines Nesting in Northern Mixed-Grass Prairie Treated With Fire
}

\author{
TODD A. GRANT, ${ }^{\mathbf{1}}$ United States Fish and Wildlife Service, Souris River Basin National Wildlife Refuge Complex, 681 Salyer Road, Upham, \\ ND 58789, USA \\ TERRY L. SHAFFER, United States Geological Survey, Northern Prairie Wildlife Research Center, 8711 37th Street Southeast, Jamestown, \\ $N D$ 58401, USA \\ ELIZABETH M. MADDEN, ${ }^{2}$ United States Fish and Wildlife Service, J. Clark Salyer National Wildlife Refuge, 681 Salyer Road, Upham, \\ ND 58789, USA \\ GORDON B. BERKEY, ${ }^{3}$ United States Fish and Wildlife Service, J. Clark Salyer National Wildlife Refuge, 681 Salyer Road, Upham, \\ ND 58789, USA
}

\begin{abstract}
Prescribed fire is an important, ecology-driven tool for restoration of grassland systems. However, prescribed fire remains controversial for some grassland managers because of reported reductions in bird use of recently burned grasslands. Few studies have evaluated effects of fire on grassland bird populations in the northern mixed-grass prairie region. Fewer studies yet have examined the influence of fire on nest density or survival. In our review, we found no studies that simultaneously examined effects of fire on duck and passerine nesting. During 1998-2003, we examined effects of prescribed fire on the density of upland-nesting ducks and passerines nesting in north-central North Dakota, USA. Apparent nest densities of gadwall (Anas strepera), mallard (A. platyrhynchos), and all duck species combined, were influenced by fire history of study units, although the degree of influence was not compelling. Fire history was not related to nest densities of blue-winged teal (A. discors), northern shoveler (A. clypeata), or northern pintail (A. acuta); however, apparent nest densities in relation to the number of postfire growing seasons exhibited a strikingly similar pattern among all duck species. When compared to ducks, fire history strongly influenced apparent nest densities of clay-colored sparrow (Spizella pallida), Savannah sparrow (Passerculus sandwichensis), and bobolink (Dolichonyx oryzivorus). For most species examined, apparent nest densities were lowest in recently burned units, increased during the second postfire growing season, and stabilized or, in some cases, decreased thereafter. Prescribed fire is critical for restoring the ecology of northern mixed-grass prairies and our findings indicate that reductions in nest densities are limited mostly to the first growing season after fire. Our results support the premise that upland-nesting ducks and several grassland passerine species are adapted to periodic fires occurring at a frequency similar to that of pre-Euro-American settlement of the region. () 2011 The Wildlife Society.
\end{abstract}

KEY WORDS duck, fire effects, grassland bird, mixed-grass prairie, nest density, nesting, North Dakota, prescribed fire.

Prairie is an endangered ecosystem in North America (Samson et al. 2004) and the decline in associated avifauna is an important issue facing biologists and managers in the region (Brennan and Kuvlesky 2005, Askins et al. 2007). Public lands, such as National Wildlife Refuges (NWRs), provide important habitats for grassland-dependent species of wildlife, given the continued conversion and degradation of grasslands held in private ownership (Higgins et al. 2002, Stephens et al. 2008). Prairies in the northern Great Plains that are managed mainly by rest (no grazing or burning) become increasingly dominated by woody and introduced

Received: 21 March 2011; Accepted: 22 July 2011;

Published: 17 October 2011

${ }^{1}$ E-mail: todd_grant@fws.gov

${ }^{2}$ Present address: 108 S 9th Street, Livingston, MT 59047, USA.

${ }^{3}$ Present address: 1964 W Sego Prairie Street, Kuna, ID 83634, USA. plant species (Grant and Murphy 2005, Murphy and Grant 2005, DeKeyser et al. 2009, Grant et al. 2009), and such degraded grasslands provide poorer quality habitat for many species of grassland-dependent wildlife. In North Dakota, USA, for example, abundances were lower for several passerine species in grasslands degraded by introduced plants and woody vegetation (Madden et al. 2000, Grant et al. 2004). Management practices, such as grazing, burning, and haying, often are used to improve the quality of prairies. Annually, about 10,000-20,000 ha of grassland, mostly northern mixed-grass prairie, is periodically burned on NWRs in the Dakotas and eastern Montana (USA). Use of fire is justified to improve wildlife habitat, restore or maintain native plant communities, and reduce fuels associated with catastrophic wildfire. However, prescribed fire remains controversial for some grassland managers because of reported reductions in bird use of recently burned 
grasslands (Naugle et al. 2000). Few studies have specifically evaluated effects of fire on grassland bird populations in the northern mixed-grass prairie region. Even fewer studies have examined the influence of fire on nest density or nest survival, particularly postfire avian response in relation to years since fire or frequency of fire. Fire effects on waterfowl nesting in northern mixed-grass prairie are derived mainly from shortterm (generally 1-yr) observational studies and anecdotal accounts (reviewed in Higgins et al. 1989, Naugle et al. 2000), although a recent study in the aspen parkland of Manitoba and Saskatchewan, Canada, evaluated fire over a 6-8-yr period (Devries and Armstrong 2011). Similar fire-effects studies are not available for passerines in northern mixed-grass prairie, but are better studied in tallgrass prairie. Higgins et al. (1989), however, cautioned that results from tallgrass prairie may not be directly applied to different systems, such as mixed-grass prairie, due to differences in climate, vegetation composition and structure, and avian community composition. We found no studies that concurrently examined fire effects on ducks and passerines nesting in the northern Great Plains, despite the importance of both groups in conservation planning and implementation (Fitzgerald et al. 1999, Government Accountability Office 2007).

On NWRs and other conservation lands in our region, use of prescribed fire is deemed necessary to restore prairies degraded by woody and introduced plants or to maintain prairies in pristine condition (Grant and Murphy 2005, Murphy and Grant 2005, DeKeyser et al. 2009, Grant et al. 2009). Within our study area, vegetation cover dominated by native grasses and forbs accounted for only $15 \%$ of the contemporary plant community, whereas Kentucky bluegrass (Poa pratensis) and smooth brome (Bromus inermis) accounted for $26 \%$ and $43 \%$ cover, respectively (T. A. Grant, unpublished data). Prior to our study, prescribed fire had been implemented as an on-going strategy for reversing the detrimental changes in vegetation composition. Our study was conceived to document the response of grassland birds to management that was occurring for purposes other than "improving nesting habitat" for grassland birds (Higgins et al. 1989, Naugle et al. 2000). Specifically, our objective was to determine effects of fire history $(1,2,3$, and $\geq 4$ postfire growing seasons) on nest densities of ducks and passerines within a remnant tract of northern mixed-grass prairie undergoing restoration, where the long-term goal is a state where vegetation composition is similar to that which occurred prior to Euro-American settlement.

\section{STUDY AREA}

We conducted our study on the 23,900-ha J. Clark Salyer NWR in Bottineau County, North Dakota (about $48^{\circ} 45^{\prime} \mathrm{N}$, $\left.100^{\circ} 50^{\prime} \mathrm{W}\right)$. The refuge was within the northern mixed-grass prairie region (Partners in Flight Physiographic Area 37; Fitzgerald et al. 1999). More specifically, our study site was within the Drift Prairie landform, characterized by native sod in deep (12-15-cm surface, $25-30-\mathrm{cm}$ subsurface) loams (Bluemle 2000). Drift prairie on J. Clark Salyer NWR consisted of $25-\mathrm{km}$-long, narrow (0.5-2.0-km-wide) tracts along shallow impoundments of the Souris River. Drift prairie tracts were bordered by cropland, interspersed with scattered tracts (16-130 ha) of either annually grazed, privately owned drift prairie or former cropland seeded to introduced grasses and forbs for conservation purposes (e.g., to reduce soil erosion, provide bird nesting cover).

Vegetation was a needle grass-wheatgrass (StipaAgropyron) association intermingled with 2 exotic grasses, Kentucky bluegrass and smooth brome. Grasses and forbs were interspersed with patches of low shrub dominated by western snowberry (Symphoricarpos occidentalis). Prior to our study, the area was managed with prescribed fire (usually in the spring) in 100-200-ha blocks every 2-6 yr since the late 1960s, except during 1985-1993, when the frequency and extent of prescribed fire in North Dakota was curtailed by drought. Cattle have not grazed the area since 1950 or before. Climate was subhumid continental, with average monthly temperatures ranging from $-15^{\circ} \mathrm{C}$ in January to $20^{\circ} \mathrm{C}$ in July. Annual precipitation fluctuated during $1998-$ 2003, but mean annual level was near the long-term average $(\bar{x}=44.2 \mathrm{~cm}$ vs. $43 \mathrm{~cm}$; T. A. Grant, unpublished data).

\section{METHODS}

\section{Study Design and Data Collection}

Our study design was identical to that of Grant et al. (2010). We used a 400-ha tract of prairie comprised of 7 contiguous units, each with a unique fire history (Table 1). Beginning in 1997, we burned selected units in August-September to mimic naturally occurring late-summer fires (Higgins 1986b). Our primary variable of interest (i.e., treatment) was the number of growing seasons since the last fire had occurred (postfire growing seasons). We grouped study-unit histories (41 total 1998-2003) into 1 (i.e., current growing season), 2, 3, or $\geq 4$ postfire growing seasons (range $=1-12$ ). For example, the number of postfire growing seasons for unit $F$, which was burned in 1998 and again in 2002, was $\geq 4$ in 1998, 1 in 1999, 2 in 2000, 3 in 2001, $\geq 4$ in 2002, and 1 in 2003 (Table 1). Postfire growing seasons 4-12 were pooled based on smaller samples of available unit histories and the assumption that fire effects would be less evident as the number of postfire growing seasons increased. This assumption seemed reasonable in light of historic fire return intervals of 5-10 yr for the region (Bragg 1995).

We searched for nests of all grassland bird species (i.e., ducks, passerines, shorebirds, raptors, etc.) from mid-April to late July of each year. We located nests between $0700 \mathrm{hr}$ and $1600 \mathrm{hr}$ by flushing adult birds with a $25-\mathrm{m}$ weighted rope that had tin cans attached every $0.5 \mathrm{~m}$ (Davis 2003). Each of 7 study plots was systematically searched 6-8 times during the breeding season. We also located some nests fortuitously and, for passerines, by observing behaviors of adult birds (Grant et al. 2005). We marked nests using survey flags placed 3-5 $\mathrm{m}$ to the north and south of the nest, with the top of the flag placed just above the average height of the vegetation. Nest location was recorded via global positioning system receiver. 
Table 1. Growing seasons since last fire for 7 units within a 400-ha mixed-grass prairie complex on J. Clark Salyer National Wildlife Refuge, North Dakota, USA, 1998-2003. For purposes of analysis, we categorized the 41 unit-year combinations into $1(n=11), 2(n=11), 3(n=7)$, or $\geq 4(n=12)$ growing seasons since last fire.

\begin{tabular}{|c|c|c|c|c|c|c|c|}
\hline \multirow[b]{2}{*}{ Unit } & \multirow[b]{2}{*}{ Area (ha) } & \multicolumn{6}{|c|}{ Year } \\
\hline & & 1998 & 1999 & 2000 & 2001 & 2002 & 2003 \\
\hline A & 69 & 8 & $9^{a}$ & 1 & 2 & 3 & 4 \\
\hline $\mathrm{C}$ & 43 & 1 & 2 & 3 & $4^{\mathrm{a}}$ & 1 & 2 \\
\hline $\mathrm{D}$ & 69 & 5 & $6^{\mathrm{a}}$ & 1 & 2 & $3^{\mathrm{a}}$ & 1 \\
\hline $\mathrm{F}$ & 69 & $5^{\mathrm{a}}$ & 1 & 2 & 3 & $4^{a}$ & 1 \\
\hline $\mathrm{G}$ & 49 & $12^{\mathrm{a}}$ & 1 & 2 & $1^{\mathrm{b}}$ & 2 & 3 \\
\hline $\mathrm{H}$ & 47 & 1 & 2 & 3 & $4^{\mathrm{a}}$ & 1 & 2 \\
\hline I & 41 & 2 & 3 & 4 & $5^{\mathrm{a}}$ & 1 & 2 \\
\hline
\end{tabular}

${ }^{\text {a }}$ Indicates year during which we completed late-summer prescribed burns.

${ }^{\text {b }}$ We excluded unit G from study in 2001 because we burned it in spring 2001 rather than late summer 2000, as scheduled.

Each year, we measured the structure of vegetation during late June through mid-July on 100-m-radius plots (4-7 plots within each burn unit) used to survey birds in a companion study (see Grant et al. 2010:1843 for details). Specifically, we measured litter depth, defined as the thickness $(\mathrm{cm})$ of dead, unconsolidated (mostly horizontal) plant matter; standing dead vegetation, defined as the percentage of standing vegetation that is dead; and maximum vegetation height $(\mathrm{cm})$, defined as the tallest vegetation contact. We averaged data across 4-7 plots, for an overall mean for each burn unit (Grant et al. 2010).

\section{Nest Density and Imperfect Nest Detection}

We estimated nest density as the number of nests detected divided by the area searched for the 8 species we studied. Because we systematically searched units multiple times throughout the season, nest detection was dependent on 1) how long an individual nest persisted, and 2) probability an adult was at the nest and flushed in response to disturbance from the rope (Giovanni et al. 2011). We did not quantify the latter probability and instead assumed it did not vary with fire history of units. Grant et al. (2005) described an estimator for number of nests initiated that accounts for nests that fail (mostly by predation) before they can be discovered. Application of their estimator to our data for duck species was straightforward. However, application of the method for passerine species was complicated by the fact that nest survival was influenced both by predation and nest parasitism by brown-headed cowbirds (Molothrus ater), particularly for Savannah sparrow (Passerculus sandwichensis) and, to a lesser extent, bobolink (Dolichonyx oryzivorus), where parasitism interacted with the fire history of units (T. A. Grant, unpublished data). In cases where we were successful in applying the Grant et al. (2005) estimator (all species except Savannah sparrow), least-squares mean estimates (Milliken and Johnson 1984:156) of detection-corrected nest density with respect to number of postfire growing seasons were strongly correlated with those of uncorrected nest densities reported here (e.g., $r$ [Pearson correlation here and hereafter] ranged from 0.75 for mallard [Anas platyrhynchos] to $>0.99$ for blue-winged teal [A. discors] and clay-colored sparrow [Spizella pallida], $n=4)$. We term these uncorrected densities as "apparent nest densities" throughout the paper. To further justify our use of apparent nest densities, we compared the pattern of apparent nest densities with respect to number of postfire growing seasons for clay-colored sparrow, Savannah sparrow, and bobolink to the pattern of independently derived estimates of relative abundance from Grant et al. (2010). The pattern of response to fire was nearly identical for the 2 metrics. Studies like ours that do not mark individuals cannot distinguish first nests from renests or second nests within a year, although we have no evidence that these nest attempts were related to fire history of study units.

\section{Fire Effects on Nest Density}

For each species, all duck species combined, and all passerine species combined, we utilized apparent nest densities in each of $41 \mathrm{yr}$-burn unit combinations ( 7 burn units and $6 \mathrm{yr}$; Table 1). We report results from a linear mixed model implemented in PROC MIXED (SAS Institute 2004) to estimate effect of postfire growing seasons on nest density. The model contained additive effects of year and number of postfire growing seasons and was based on the assumption of normally distributed data. Because we surveyed the same units in multiple years, repeated measures were potentially correlated. We modeled the correlation assuming an exchangeable correlation structure $(\mathrm{TYPE}=\mathrm{CS}$ in PROC MIXED). We report least-squares mean estimates (Milliken and Johnson 1984) of nest density by year and postfire growing seasons. We considered alternative models (implemented in SAS PROC GLIMMIX) that recognized our data as counts and imposed either overdispersed-Poisson or negative binomial distributional assumptions; results of those analyses, including model-based estimates of nest density, were consistent with results we report.

We anticipated that changes in precipitation would partly explain year effects we might observe. We calculated annual precipitation as the amount received from 1 January to 31 December of the previous year (measured using weather station at refuge headquarters), and computed Pearson correlation coefficients between precipitation and annual estimates of nest density. We believe this measure of precipitation accounted for moisture received during the previous year (known to affect vegetation structure during the subsequent growing season; Grant et al. 2010) and 
captured an effect associated with several consecutive years (1999-2001) of well-above-average precipitation. We computed correlations between nest density (for individual unit-years) and vegetation structure, namely litter depth, maximum vegetation height, and percent standing dead vegetation.

\section{RESULTS}

During 1998-2003, we located 3,817 nests of 31 species, including 1,770 duck and 1,961 passerine nests (Table 2). Gadwall (A. strepera), mallard, and blue-winged teal accounted for $85 \%$ of duck nests. Savannah sparrow, claycolored sparrow, and bobolink accounted for $91 \%$ of passerine nests. Density of nests for all duck species, individually and combined, varied among years $\left(F_{5,26}=3.79-9.71\right.$, $P=0.010-0.001)$ and was highest during 1999-2001, when precipitation was above average and lowest during 1998, 2002, and 2003, when precipitation was below average $\left(r_{5}=0.76\right.$ [all duck species combined]). This pattern was consistent among all duck species we examined (Fig. 1). Apparent nest densities for ducks were more closely related to maximum vegetation height than to litter depth or standing dead vegetation (Table 3 ). Fire history was associated with apparent nest densities of gadwall $\left(F_{3,18}=2.92\right.$, $P=0.06)$, mallard $\left(F_{3,18}=4.07, P=0.02\right)$, and all duck species combined $\left(F_{3,18}=2.81, P=0.07\right)$. Densities were

Table 2. Number of nests and percentage of the overall sample of nests for 31 species of birds breeding in grasslands on J. Clark Salyer National Wildlife Refuge, North Dakota, USA, 1998-2003.

\begin{tabular}{|c|c|c|}
\hline Species & Nests & Percent \\
\hline American bittern (Botaurus lentiginosus) & 2 & $<1$ \\
\hline Gadwall (Anas strepera) & 521 & 14 \\
\hline American wigeon (Anas americana) & 12 & $<1$ \\
\hline Mallard (Anas platyrhynchos) & 331 & 9 \\
\hline Blue-winged teal (Anas discors) & 645 & 17 \\
\hline Northern shoveler (Anas clypeata) & 179 & 5 \\
\hline Northern pintail (Anas acuta) & 75 & 2 \\
\hline Green-winged teal (Anas crecca) & 2 & $<1$ \\
\hline Redhead (Aythya americana) & 1 & $<1$ \\
\hline Lesser scaup (Aythya affinis) & 4 & $<1$ \\
\hline Northern harrier (Circus cyaneus) & 21 & $<1$ \\
\hline Sharp-tailed grouse (Tympanuchus phasianellus) & 16 & $<1$ \\
\hline Sora (Porzana carolina) & 1 & $<1$ \\
\hline Killdeer (Charadrius vociferus) & 1 & $<1$ \\
\hline Upland sandpiper (Bartramia longicauda) & 34 & $<1$ \\
\hline Wilson's phalarope (Phalaropus tricolor) & 2 & $<1$ \\
\hline Short-eared owl (Asio flammeus) & 9 & $<1$ \\
\hline Eastern kingbird (Tyrannus tyrannus) & 4 & $<1$ \\
\hline Sedge wren (Cistothorus platensis) & 11 & $<1$ \\
\hline Common yellowthroat (Geothlypis trichas) & 2 & $<1$ \\
\hline Clay-colored sparrow (Spizella pallida) & 813 & 21 \\
\hline Savannah sparrow (Passerculus sandwichensis) & 754 & 20 \\
\hline Grasshopper sparrow (Ammodramus savannarum) & 11 & $<1$ \\
\hline Baird's sparrow (Ammodramus bairdii) & 3 & $<1$ \\
\hline Le Conte's sparrow (Ammodramus leconteii) & 45 & 1 \\
\hline Song sparrow (Melospiza melodia) & 7 & $<1$ \\
\hline Chestnut-collared longspur (Calcarius ornatus) & 20 & $<1$ \\
\hline Bobolink (Dolichonyx oryzivorus) & 203 & 5 \\
\hline Red-winged blackbird (Agelaius phoeniceus) & 47 & 1 \\
\hline Western meadowlark (Sturnella neglecta) & 26 & $<1$ \\
\hline Brewer's blackbird (Euphagus cyanocephalus) & 15 & $<1$ \\
\hline Total & 3,817 & \\
\hline
\end{tabular}
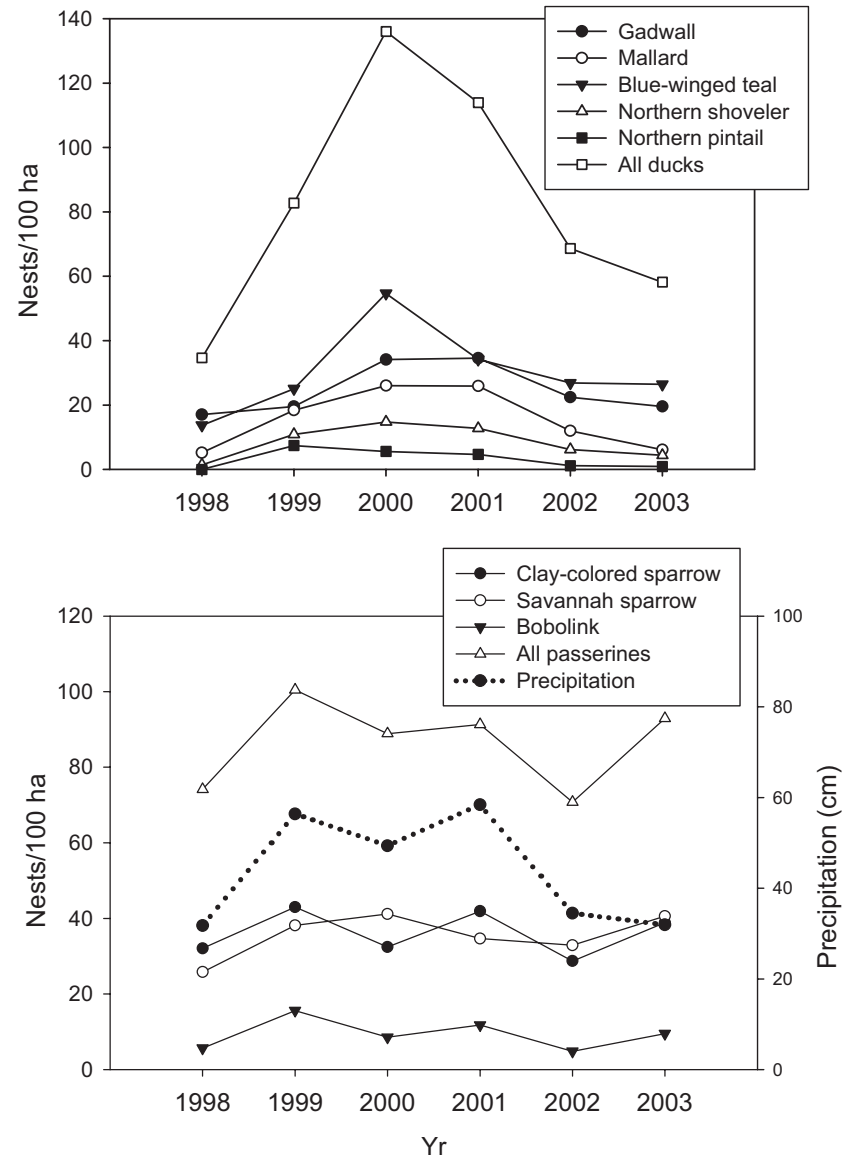

Figure 1. Estimates of apparent nest densities and annual precipitation among years 1998-2003 on J. Clark Salyer National Wildlife Refuge, North Dakota, USA. Density estimates are least-squares means from a repeated-measures linear model with fixed effects for postfire growing seasons $(1,2,3$, or $\geq 4)$ and year. Annual precipitation is recorded from 1 January to 31 December of the previous year. Mean annual precipitation was $44.2 \mathrm{~cm}$ during 1998-2003.

lowest during the first postfire growing season, then increased and stabilized during subsequent growing seasons, although gadwall nesting appeared to decline in units $\geq 4 \mathrm{yr}$ postfire (Figs. 2 and 3). Fire did not influence apparent nest densities of blue-winged teal $\left(F_{3,18}=1.15, P=0.36\right)$, northern shoveler (A. clypeata; $F_{3,18}=0.67, P=0.58$ ), or northern pintail ( $A$. acuta; $F_{3,18}=0.97, P=0.43$ ), although the pattern of nesting in relation to postfire growing seasons was similar among all duck species (Fig. 3).

Density of nests for clay-colored sparrow, Savannah sparrow, bobolink, and all passerine species combined did not vary among years $\left(F_{5,26}=0.62-2.03, \quad P=0.69-0.11\right)$; however, the pattern of nesting among years closely matched that of annual precipitation (Fig. 1; $r_{5}=0.67$ [all passerine species combined]). Except for bobolink, apparent nest densities of other passerines and all passerines combined were more closely related to litter depth and standing dead vegetation than to maximum vegetation height (Table 3). Apparent nest densities of clay-colored sparrow $\left(F_{3,18}=\right.$ $10.19, \quad P<0.001)$, Savannah sparrow $\left(F_{3,18}=12.47\right.$, $P<0.001)$, bobolink $\left(F_{3,18}=6.73, P=0.003\right)$, and all 
Table 3. Correlation coefficients between nest density and vegetation structure for ducks and passerines breeding on J. Clark Salyer National Wildlife Refuge, North Dakota, USA, 1998-2003. Values in bold represent $r>0.40$.

\begin{tabular}{|c|c|c|c|}
\hline Species & $\begin{array}{l}\text { Litter } \\
\text { depth }\end{array}$ & $\begin{array}{c}\text { Maximum } \\
\text { ht }\end{array}$ & $\begin{array}{c}\text { Standing } \\
\text { dead }\end{array}$ \\
\hline \multicolumn{4}{|l|}{ Ducks } \\
\hline Gadwall (Anas strepera) & 0.26 & 0.48 & 0.35 \\
\hline Mallard (A. platyrbynchos) & 0.50 & 0.59 & 0.35 \\
\hline Blue-winged teal (A. discors) & 0.17 & 0.43 & 0.25 \\
\hline Northern shoveler (A. clypeata) & 0.35 & 0.56 & 0.11 \\
\hline Northern pintail (A. acuta) & 0.40 & 0.66 & -0.01 \\
\hline All ducks ${ }^{\mathrm{a}}$ & 0.37 & 0.61 & 0.31 \\
\hline \multicolumn{4}{|l|}{ Passerines } \\
\hline $\begin{array}{l}\text { Clay-colored sparrow } \\
\text { (Spizella pallida) }\end{array}$ & 0.62 & 0.23 & 0.61 \\
\hline $\begin{array}{l}\text { Savannah sparrow } \\
\quad \text { (Passerculus sandwichensis) }\end{array}$ & 0.49 & 0.28 & 0.63 \\
\hline Bobolink (Dolichonyx oryzivorus) & -0.11 & 0.27 & 0.16 \\
\hline All passerines ${ }^{\mathrm{a}}$ & 0.57 & 0.37 & 0.68 \\
\hline
\end{tabular}

${ }^{a}$ Includes species not listed in the table.

passerine species combined $\left(F_{3,18}=17.25, P<0.001\right)$ were more influenced by fire history than what we observed for ducks. Densities for both sparrows were approximately 9-11 nests/100 ha during the first postfire growing season, increased to about 30-50 nests/100 ha during the second and third postfire growing season, and stabilized thereafter (Fig. 3). Bobolink nest density was 7.2 nests/100 ha during the first postfire growing season, increased to 17.5 nests/ 100 ha during the second postfire growing season, and declined thereafter (Fig. 3).

Fire influenced vegetation structure by altering litter depth $\left(F_{3,18}=52.2, P<0.001\right)$ and standing dead vegetation $\left(F_{3,18}=140.44, P<0.001\right)$. Less apparent was the influence of fire on maximum vegetation height $\left(F_{3,18}=2.88\right.$, $P=0.065)$. All 3 parameters were lowest during the first postfire growing season (Fig. 2). Standing dead vegetation and litter depth increased 4-6-fold, respectively, during the second postfire growing season. Standing dead vegetation and maximum vegetation height stabilized during growing seasons 2 and 3, whereas plant litter accumulated 1-2 cm during each postfire growing season (Fig. 2).

\section{DISCUSSION}

During 1998-2003, fire history of units and changes in annual precipitation influenced vegetation structure, which, in turn, affected nesting by ducks and passerines. Apparent nest densities for ducks were related to maximum vegetation height, which, of the 3 vegetation parameters we measured, was least influenced by fire. This may explain the relatively minor influence of fire on duck nest densities that we observed. In contrast, fire greatly altered litter depth and standing dead vegetation, which may, in turn, explain the more influential response of passerines to fire history, especially compared to that we observed for ducks. For most species considered, apparent nest densities were lowest during the first postfire growing season, increased during the second postfire growing season, and stabilized or, in some cases, decreased thereafter.
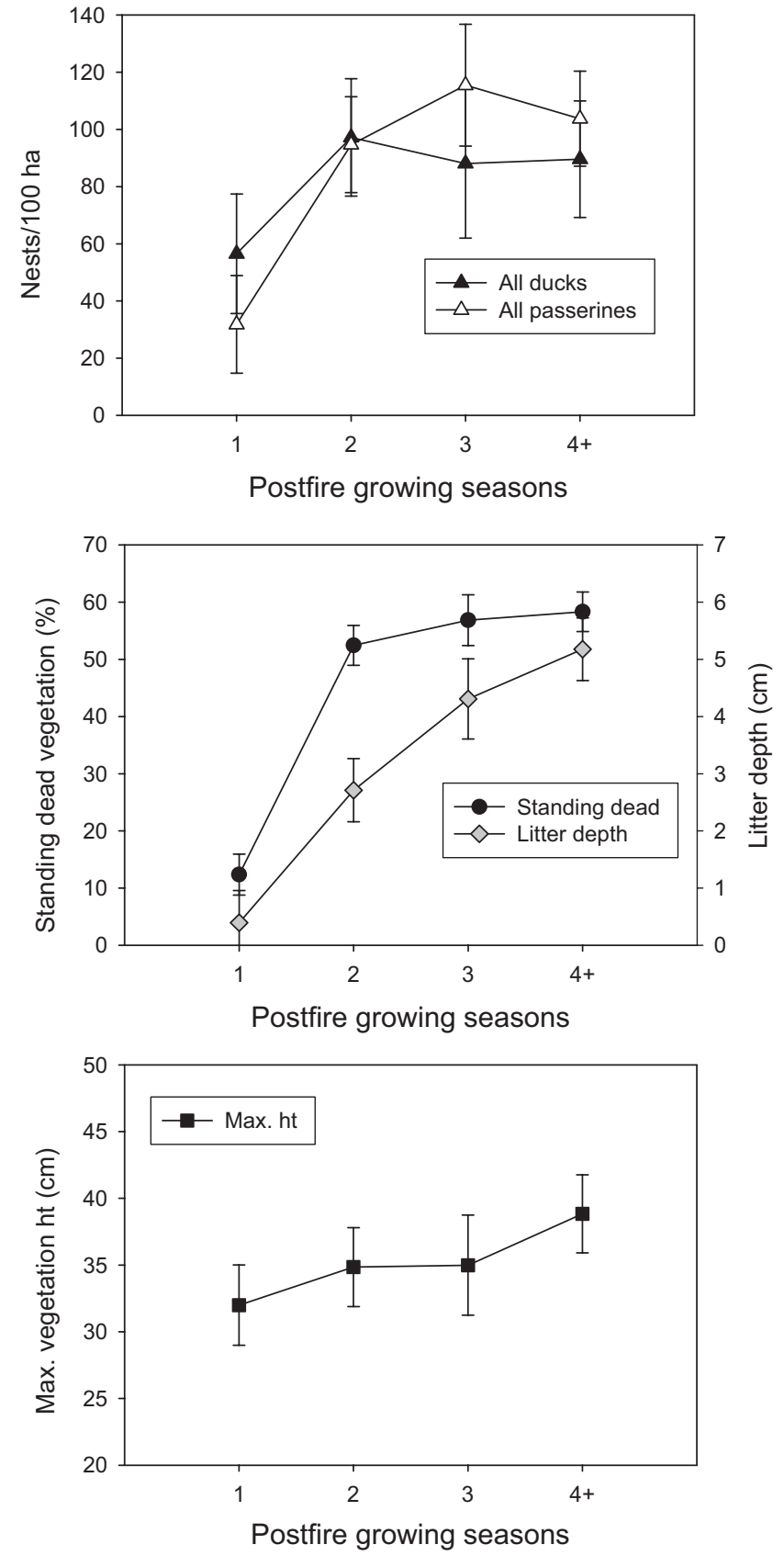

Figure 2. Estimates of vegetation structure and apparent nest densities for all duck and passerine species combined in relation to the number of postfire growing seasons (1, 2, 3, or $\geq 4)$ on J. Clark Salyer National Wildlife Refuge, North Dakota, USA, 1998-2003. Density estimates are least-squares means from a repeated-measures linear model with fixed effects for postfire growing seasons and year. Error bars represent $95 \%$ confidence intervals.

\section{Fire Effects on Grassland Birds}

Few studies have examined the influence of fire on bird nesting in northern mixed-grass prairie. We were particularly surprised how limited data were concerning fire effects on waterfowl nesting, given the importance of waterfowl in setting management objectives for the region (Government Accountability Office 2007) and the widespread use of prescribed fire on NWRs and other conservation lands during the past $40 \mathrm{yr}$. Some fire accounts were anecdotal (e.g., Glover 1956, Martz 1967), while others used 

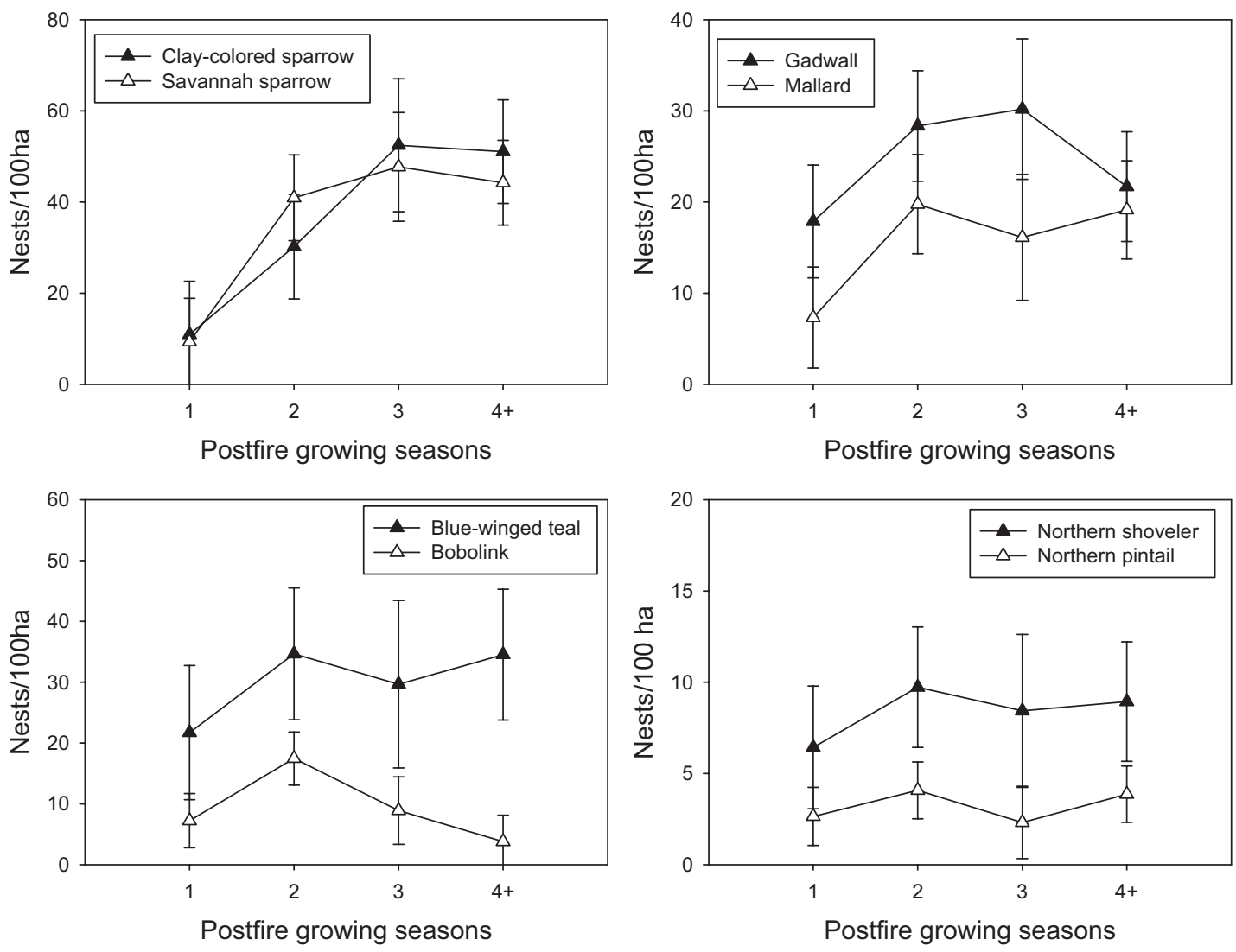

Figure 3. Apparent nest densities for 5 duck and 3 passerine species in relation to the number of postfire growing seasons $(1,2,3$, or $\geq 4)$ on J. Clark Salyer National Wildlife Refuge, North Dakota, USA, 1998-2003. Density estimates are least-squares means from a repeated-measures linear model with fixed effects for postfire growing seasons and year. Error bars represent $95 \%$ confidence intervals.

data pooled across all duck species, a technique that is rarely justified except when small samples preclude more effective analyses. For example, Fritzell (1975) found lower nest densities for all duck species combined during the first growing season after spring burning of wetland, roadside, and cropland edges compared to idled cover in a Canadian agricultural landscape. Kirsch and Kruse (1973) studied duck nesting in North Dakota on 3 plots, 2 of which were burned in May of the previous year, and 1 control plot that was rested. They found similar numbers of duck nests on areas that were burned in May of the previous year, but with one complete growing season since fire compared to the unburned control plot (this treatment is analogous to 2 postfire growing seasons in our study, where units were burned in Aug to Sep). In an expanded study that included data from Kirsch and Kruse (1973), 8 species of upland-nesting ducks used mixed-grass prairie sites regardless of whether tracts were idled, burned, or grazed (within-year densities); however, nest densities were greater in idle native prairie tracts (26.7 nests/40.5 ha) than in burned tracts (14.7 nests/ 40.5 ha; Higgins et al. 1992). Higgins (1986a) compared spring and autumn burning on 5 mixed-grass prairie tracts in North Dakota and observed the lowest duck-nesting response during the first postfire growing season, likely related to reduced vegetation height and density. By the second growing season after fire, the number of nests was nearly equal on spring- and autumn-burned plots and remained similar during the third and fourth postfire growing seasons. Kruse and Bowen (1996) found no difference in densities among spring burn plots, grazed plots, burn-graze plots, and control plots for any duck species they studied. However, habitat changes and poor reproductive success associated with drought led to potentially insufficient power to detect fire effects and may have complicated interpretation of their results. In a recent study conducted in aspen parkland region of Manitoba and Saskatchewan, duck nest density was 0.7 nests/ha the first year following management (i.e., haying and burning), nearly doubled in years $2-3$, and declined back to approximately 0.7 nests/ha for sites with $\geq 6 \mathrm{yr}$ postmanagement, results similar to our data (Devries and Armstrong 2011).

Effects of fire on passerine occurrence, density, and relative abundance in northern mixed-grass prairie were recently reviewed in Grant et al. (2010). To our knowledge, effects of fire on passerine nesting (i.e., density or survival) have not been examined in the region. Available studies that have examined these effects are from other grassland systems, particularly tallgrass prairie. The mean number of nests for eastern meadowlark (Sturnella magna), grasshopper sparrow (Ammodramus savannarum), and dickcissel (Spiza americana) did not differ between undisturbed and disturbed (grazing and burning) plots at a tallgrass prairie site in Oklahoma, USA (Rohrbaugh et al. 1999). These 3 passerine species selected burned sites over undisturbed sites during 
another study in Oklahoma (Shochat et al. 2005). Fewer bird nests (all species combined) were found in fields enrolled in the Conservation Reserve Program during the first postfire growing season (spring fires) than during $2-4$ postfire growing seasons (Robel et al. 1998).

In a review of studies that examined management effects (including fire effects) on grassland birds in the northern Great Plains, Naugle et al. (2000) concluded that most studies lacked research designs necessary to effectively evaluate bird response to changes in grassland structure modified by defoliation events (i.e., fire, grazing, or haying). In a companion study to ours, Grant et al. (2010) demonstrated fire-induced changes in vegetation structure as a probable mechanism to explain grassland passerine response (relative abundance derived from point counts) to fire. Specifically, they found that fire-induced changes in vegetation structure (litter, standing dead vegetation, and max vegetation ht) influenced species richness and relative abundance for 5 species of grassland passerines and for all passerine species combined. In general, bird use declined the first year following fire but increased and often stabilized within 2-3 postfire growing seasons, results nearly identical to our data for apparent nest densities of clay-colored sparrow, Savannah sparrow, and bobolink. Devries and Armstrong (2011) also reported that litter depth and visual obstruction readings were reduced during the first year after management (fire and haying), and that changes in vegetation structure influenced duck nest density.

\section{Balancing the Ecological Role of Fire with Bird Nesting}

Duck nest densities in grasslands that are idled are generally reported to be greater than for grasslands recently (previous autumn or current spring) burned, grazed, or hayed (see review by Naugle et al. [2000], also see Devries and Armstrong [2011]). Kirsch (1969) was among the first to advocate discontinuation of practices that removed grassland cover because duck nesting was expected to be lower compared to grasslands that were idled. Similar recommendations were made by Kruse and Bowen (1996:244), who concluded that "manipulations (grazing, fire, or grazing and fire) we studied were detrimental to most species of upland-nesting waterfowl, at least in some years." In these and similar treatment-control studies, prescribed fire was classified as detrimental or, at best, neutral for upland-nesting duck species, despite evidence that grassland birds are flexible and often renest or occupy adjacent unburned habitat rather than die or emigrate from the area as a result of fire (Naugle et al. 2000). Many of these studies also lacked data on longer term effects of fire. Fire and/or grazing are recommended at 3-10-yr intervals in northern grasslands (primarily to reduce accumulation of litter); furthermore, treatments should be deferred for several years (i.e., undermanage) in cases where managers are uncertain whether such actions are necessary (Naugle et al. 2000). Under this scenario, years of rest (i.e., no defoliation treatments) are increased. Infrequent defoliation may increase attractiveness of grasslands for duck nesting (at least in the short term), especially for species such as gadwall and mallard that are attracted to cover that is tall and dense (reviewed in Naugle et al. 2000). However, long-term changes in composition of prairie plant communities related to fire frequency have rarely been assessed, despite growing evidence that degraded grasslands offer less suitable habitat for many grassland bird species (e.g., Kirsch et al. 1978; Madden et al. 2000; Grant et al. 2004, 2010). This is especially apparent for areas managed with long-term rest, because these are among the most degraded grasslands on NWRs and other lands in the Dakotas (DeKeyser et al. 2009, Grant et al. 2009). Prescribed fire continues to gain greater acceptance as a restoration and maintenance tool for grassland managers, although research documenting postfire responses for grassland birds has not kept pace. In northern mixed-grass prairie, additional study is required that documents short- and longterm nesting responses across a broad suite of grassland bird species, as is research documenting nest survival in response to fire.

Because our study was conducted at a single site, wide inferences drawn from our data should be viewed with caution. Furthermore, use of prescribed fire was assumed in our study, based on the requisite that fire is a necessary component for prairie restoration (Madden et al. 1999, Murphy and Grant 2005, Grant et al. 2010). Significantly, the northern Great Plains evolved with grazing and fire disturbances (Higgins 1986b, Manske 2000), as well as climatic variability (Bragg 1995). Natural and anthropogenic fires occurred roughly every $5-10 \mathrm{yr}$ in northern mixedgrass prairie (Bragg 1995), with north-central and northwestern North Dakota estimated near the 5-6-yr end of this range (Madden et al. 1999, Grant et al. 2010). Beginning with Euro-American settlement, these fires were suppressed (Umbanhowar 1996). Changes in the prairie plant and animal community associated with decades of fire suppression are alarming, because many changes may be irreversible (Madden et al. 1999; Murphy and Grant 2005; Grant et al. 2009, 2010). Few prairies in the northern Great Plains are managed such that the interaction of drought, fire, and grazing mimic natural conditions (i.e., frequency, timing, and extent of disturbances) under which grassland plant and animal species evolved. Maintenance and restoration of prairies is further exacerbated by widespread invasions of introduced plant species (e.g., smooth brome and Kentucky bluegrass). An adaptive approach to prairie management that better considers forces that shaped northern grasslands, while also addressing invasive plant issues, has been recommended for NWRs and other prairies in the region (Grant et al. 2009, 2010) and is being developed (Gannon et al. 2011); the need for thorough documentation of plant and animal responses to management (including fire) is obvious.

\section{MANAGEMENT IMPLICATIONS}

Because reductions in apparent nest densities were limited mostly to the first growing season after fire, our results indicate that upland-nesting ducks and $\geq 3$ grassland passerines are adapted to periodic fires, of frequency corresponding 
to the era preceding Euro-American settlement of the region. Duck species appear less influenced by recent fire than passerines because they were associated with actively growing vegetation (i.e., max vegetation ht), whereas passerines responded to residual vegetation from previous growing seasons (i.e., litter, standing dead) that was greatly reduced immediately following fire. Because most species of grassland birds are persistent renesters (i.e., they select or move to adjacent unburned habitats), prescribed fire conducted at spatial or temporal scales that match available resources similar to that of NWRs in our region likely does not appreciably affect local or regional grassland bird populations, via its influence on nesting density. Fires prescribed at lower frequencies (e.g., $>10-y r$ intervals) may increase nest densities for some species in the short term. However, this approach poses significant long-term risks to grassland bird populations because degraded prairies ultimately reduce habitat use by many obligate grassland bird species.

\section{ACKNOWLEDGMENTS}

Funding was provided by the U.S. Fish and Wildlife Service, Region 6 Divisions of Refuges and Wildlife and Migratory Bird Management; by the U.S. Geological Survey, Northern Prairie Wildlife Research Center; and by the Joint Fire Science Program. We especially thank S. L. Jones for support of the project with advice and funding. We are grateful to $S$. K. Davis for sharing his experience and methods for locating and monitoring nests of grassland passerines. C. M. Aucoin, B. Bedard, K. J. Berg, B. Cofell, K. M. BausChristopherson, M. J. Friel, J. Gault, K. M. Hansen, S. L. Kempema, S. Kuzyk, R. A. Laubhan, S. A. Marshall, R. T. McManus, M. P. Nenneman, and J. J. Thury assisted with data collection. We thank T. W. Arnold, K. K. Bakker, L. D. Igl, M. P. Nenneman, S. K. Davis, J. Walker, and an anonymous reviewer for comments that improved the manuscript. The findings and conclusions in this article are those of the authors and do not necessarily represent the views of the U.S. Fish and Wildlife Service. The use of trade, product, or firm names in this article is for descriptive purposes only and does not imply endorsement by the U.S. Government.

\section{LITERATURE CITED}

Askins, R. A., F. Chávez-Ramírez, B. C. Dale, C. A. Haas, J. R. Herkert, F. L. Knopf, and P. D. Vickery. 2007. Conservation of grassland birds in North America: understanding ecological processes in different regions. Ornithological Monographs 64:1-46.

Bluemle, J. P. 2000. The face of North Dakota. Third edition. North Dakota Geological Survey Educational Series 26, Bismarck, USA.

Bragg, T. B. 1995. The physical environment of Great Plains grasslands. Pages 49-81 in A. Joern and K. H. Keeler, editors. The changing prairie. Oxford University Press, New York, New York, USA.

Brennan, L. A., and W. P. Kuvlesky, Jr. 2005. North American grassland birds: an unfolding conservation crisis? Journal of Wildlife Management 69:1-13.

Davis, S. K. 2003. Nesting ecology of mixed-grass prairie songbirds in southern Saskatchewan. Wilson Bulletin 115:119-130.

DeKeyser, S., G. Clambey, K. Krabbenhoft, and J. Ostendorf. 2009. Are changes in species composition on central North Dakota rangelands due to non-use management? Rangelands 31:16-19.
Devries, J. H., and L. M. Armstrong. 2011. Impact of management treatments on waterfowl use of dense nesting cover in the Canadian parklands. Journal of Wildlife Management 75:1340-1349.

Fitzgerald, J. A., D. N. Pashley, and B. Pardo. 1999. Partners in Flight bird conservation plan for the northern mixed-grass prairie (Physiographic Area 37). Missouri Department of Conservation, Jefferson City, USA. http://www.partnersinflight.org/bcps/plan/pl_37_10.pdf. Accessed 22 Nov 2008

Fritzell, E. K. 1975. Effects of agricultural burning on nesting waterfowl. Canadian Field-Naturalist 89:21-27.

Gannon, J. J., C. T. Moore, T. L. Shaffer, and B. Flanders-Wanner. 2011. An adaptive approach to invasive plant management on fish and wildlife service-owned native prairies in the prairie pothole region: decision support under uncertainty. Pages 136-145 in D. Williams, B. Butler, and D. D. Smith, editors. Restoring a national treasure: proceedings of the twenty-second North American prairie conference. University of Northern Iowa, Cedar Falls, IA.

Giovanni, M. D., M. Post van der Burg, L. C. Anderson, L. A. Powell, W. H. Schacht, and A. J. Tyre. 2011. Estimating nest density when detectability is incomplete: variation in nest attendance and response to disturbance by western meadowlarks. Condor 113:223-232.

Glover, F. A. 1956. Nesting and production of the blue-winged teal in northwestern Iowa. Journal of Wildlife Management 20:28-46.

Government Accountability Office. 2007. Prairie Pothole Region: at the current pace of acquisitions, the U.S. Fish and Wildlife Service is unlikely to achieve its habitat protection goals for migratory birds. Report to Congress by Government Accountability Office Online. <www. ppjv.org/PPJV_presntations/d071093.pdf>. Accessed 22 Nov 2008.

Grant, T. A., B. Flanders-Wanner, T. L. Shaffer, R. K. Murphy, and G. A. Knutsen. 2009. An emerging crisis across northern prairie refuges: prevalence of invasive plants and a plan for adaptive management. Ecological Restoration 27:58-65.

Grant, T. A., E. M. Madden, and G. B. Berkey. 2004. Tree and shrub invasion in northern mixed-grass prairie: implications for breeding grassland birds. Wildlife Society Bulletin 32:807-818.

Grant, T. A., E. M. Madden, T. L. Shaffer, and J. S. Dockens. 2010. Effects of prescribed fire on vegetation and passerine birds in northern mixedgrass prairie. Journal of Wildlife Management 74:1841-1851.

Grant, T. A., and R. K. Murphy. 2005. Changes in woodland cover on prairie refuges in North Dakota, USA. Natural Areas Journal 25:359368.

Grant, T. A., T. L. Shaffer, E. M. Madden, and P. J. Pietz. 2005. Timespecific variation in passerine nest survival: new insights for old questions. Auk 122:661-672.

Higgins, K. F. 1986a. Comparison of burn season effects on nesting birds in North Dakota mixed-grass prairie. Prairie Naturalist 18:219228.

Higgins, K. F. 1986b. Interpretation and compendium of historical fire accounts in the northern Great Plains. U.S. Fish and Wildlife Service Resource Publication No. 161, Washington, D.C., USA.

Higgins, K. F., L. M. Kirsch, A. T. Klett, and H. W. Miller. 1992. Waterfowl production on the Woodworth Station in south-central North Dakota, 1965-1981. U.S. Fish and Wildlife Service Resource Publication 180, Washington, D.C., USA.

Higgins, K. F., A. D. Kruse, and J. L. Piehl. 1989. Effects of fire in the Northern Great Plains. U.S. Fish and Wildlife Service and Cooperative Extension Service Extension, Circular 761, South Dakota State University, Brookings, USA.

Higgins, K. F., D. E. Naugle, and K. J. Forman. 2002. A case study of changing land use practices in the northern Great Plains, USA: an uncertain future for waterbird conservation. Waterbirds 25(Special Publication 2):42-50.

Kirsch, L. M. 1969. Waterfowl production in relation to grazing. Journal of Wildlife Management 33:821-828.

Kirsch, L. M., H. F. Duebbert, and A. D. Kruse. 1978. Grazing and haying effects on habitats of upland nesting birds. Transactions of the North American Wildlife and Natural Resource Conference 43:486-497.

Kirsch, L. M., and A. D. Kruse. 1973. Prairie fires and wildlife. Proceedings of the Tall Timbers Fire Ecology Conference 12:289-303.

Kruse, A. D., and B. S. Bowen. 1996. Effects of grazing and burning on densities and habitats of breeding ducks in North Dakota. Journal of Wildlife Management 60:233-246. 
Madden, E. M., A. J. Hansen, and R. K. Murphy. 1999. Influence of prescribed fire history on habitat and abundance of passerine birds in northern mixed-grass prairie. Canadian Field-Naturalist 113:627640.

Madden, E. M., R. K. Murphy, A. J. Hansen, and L. Murray. 2000. Models for guiding management of prairie bird habitat in northwestern North Dakota. American Midland Naturalist 144:377-392.

Manske, L. L. 2000. Prehistoric conditions of rangelands in the northern Great Plains. North Dakota State University, Summary Range Management Report DREC 99-3015. < http://www.ag.ndsu.nodak. edu/dickinso/research/1999/range99e.htm>. Accessed 22 Nov 2008.

Martz, G. F. 1967. Effects of nesting cover removal on breeding puddle ducks. Journal of Wildlife Management 31:236-247.

Milliken, G. A., and D. E. Johnson. 1984. Analysis of messy data. Volume 1: designed experiments. Van Nostrand Reinhold, New York, New York, USA.

Murphy, R. K., and T. A. Grant. 2005. Land management history and floristics in mixed-grass prairie, North Dakota, USA. Natural Areas Journal 25:351-358.

Naugle, D. E., K. F. Higgins, and K. K. Bakker. 2000. A synthesis of the effects of upland management practices on waterfowl and other birds in the northern Great Plains of the U.S. and Canada. Wildlife Technical Report 1. College of Natural Resources, University of Wisconsin-Stevens Point, USA
Robel, R. J., J. P. Hughes, S. D. Hull, K. E. Kemp, and D. S. Klute. 1998. Spring burning: resulting avian abundance and nesting in Kansas CRP. Journal of Range Management 51:132-138.

Rohrbaugh, R. W., Jr., D. L. Reinking, D. H. Wolfe, S. K. Sherrod, and M. A. Jenkins. 1999. Effects of prescribed burning and grazing on nesting and reproductive success of three grassland passerine species in tallgrass prairie. Studies in Avian Biology 19:165-170.

Samson, F. B., F. L. Knopf, and W. R. Ostlie. 2004. Great Plains ecosystems: past, present, and future. Wildlife Society Bulletin 32:6-15.

SAS Institute. 2004. SAS OnlineDoc 9.1.2. SAS Institute, Cary, North Carolina, USA. <http://support.sas.com/onlinedoc/912/docMainpage. jsp >. Accessed 24 Apr 2010.

Shochat, E., M. A. Patten, D. W. Morris, D. L. Reinking, D. H. Wolfe, and S. K. Sherrod. 2005. Ecological traps in isodars: effects of tallgrass prairie management on bird nest success. Oikos 111:159-169.

Stephens, S. E., J. A. Walker, D. R. Blunck, A. Jayaraman, D. E. Naugle, J. K. Ringelman, and A. J. Smith. 2008. Predicting risk of habitat conversion in native temperate grasslands. Conservation Biology 22: 1320-1330.

Umbanhowar, C. E., Jr. 1996. Recent fire history of the northern Great Plains. American Midland Naturalist 135:115-121.

Associate Editor: Haukos. 